\title{
Pore Radius and Permeability Prediction from Sonic Velocity
}

\author{
Mbia, Ernest Ncha; Fabricius, Ida Lykke
}

Published in:

Proceedings of Third EAGE Shale Workshop Shale Physics and Shale Chemistry

Publication date:

2012

Document Version

Publisher's PDF, also known as Version of record

Link back to DTU Orbit

Citation (APA):

Mbia, E. N., \& Fabricius, I. L. (2012). Pore Radius and Permeability Prediction from Sonic Velocity. In Proceedings of Third EAGE Shale Workshop Shale Physics and Shale Chemistry: New Plays, New Science, New Possibilities

\section{General rights}

Copyright and moral rights for the publications made accessible in the public portal are retained by the authors and/or other copyright owners and it is a condition of accessing publications that users recognise and abide by the legal requirements associated with these rights.

- Users may download and print one copy of any publication from the public portal for the purpose of private study or research.

- You may not further distribute the material or use it for any profit-making activity or commercial gain

- You may freely distribute the URL identifying the publication in the public portal

If you believe that this document breaches copyright please contact us providing details, and we will remove access to the work immediately and investigate your claim 


\title{
C04 Pore Radius and Permeability Prediction from Sonic Velocity
}

\author{
E.N. Mbia (Technical University of Denmark) \& I.L. Fabricius (Technical University of Denmark)
}

\section{Introduction}

Several authors have predicted permeability of shales either through laboratory measurements and or from field data using various empirical relations. A critical literature review by Mondol et al., (2008) on available permeability models, concluded that none of the existing models is ideal and all need to be calibrated and validated through a much larger permeability database of well-characterized mudstones. His results on smectite and kaolinite aggregates suggest that the permeability of smectitic clays may be up to five orders of magnitude lower than that of kaolinitic clays with the same porosity, density, velocity or rock mechanical properties. Mari et al., (2011) described a methodology for obtaining a permeability $\log$ based on acoustic velocities $V_{p}$ and $V_{s}$, porosity $\varphi$, P-wave attenuation and frequency, their calculation of the specific surface $S$ of the formation was based on the relationship between porosity $\varphi, V_{p} / V_{s}$ and $S$ proposed by Fabricius et al. (2007). Fabricius (2011) indicate that pore radius and thus permeability of shale in the depth interval of mechanical compaction may be predicted from porosity and sonic velocity. In this work we are presenting the empirical equations developed from experimental data that can be used to predict pore radius and permeability of shale from sonic velocity data measured in the field.

\section{Method and Theory}

Experimental data from Cenozoic and Jurassic shale of Skjold Flank-1 well (Mbia et al., 2011) and that of kaolinite and smectite aggregates (Mondol et al., 2007) were used. The experimental data used includes porosity $\varphi$, BET specific surface, grain density $\rho_{\mathrm{g}}$ and sonic velocities (Vp and Vs). Those of Mondol et al., (2007) are given for mixtures of kaolinite or smectite and brine. Bulk density, $\rho$, for each data point was calculated from $\varphi, \rho_{\mathrm{g}}$, and $\rho_{\mathrm{fl}}$.

$\rho=\rho_{\mathrm{g}}(1-\varphi)+\rho_{\mathrm{fl}} \varphi$

Elastic compressional modulus, $\mathrm{M}$, was calculated as: $\quad \mathrm{M}=\rho \mathrm{V}_{\mathrm{p}}^{2}$

Elastic shear modulus, G, was calculated as:

$$
\mathrm{G}=\rho \mathrm{V}_{\mathrm{s}}^{2}
$$

Elastic bulk modulus, $\mathrm{K}$, was as calculated as:

$$
\mathrm{K}=\mathrm{M}-4 / 3 \mathrm{G}
$$

For modeling pore radius, we need information on $\varphi, \rho_{\mathrm{g}}$, and on specific surface, $\mathrm{S}_{\mathrm{s}}$ of the solid.

The pore radius, $r$, is approximated by:

$$
\mathrm{r}=(2 \varphi) /\left(\mathrm{S}_{\mathrm{s}} \rho_{\mathrm{g}}(1-\varphi)\right)=2 / \mathrm{S}_{\mathrm{p}}
$$

Where $S_{p}$ is the specific surface relative to pore space.

The calculated pore radius $r$, eqn. (5) together with the moduli eqn. (2) to (4), (Fig. 2a, 2c \& 2e) were used to compute the following empirical equations which can predict pore radius $r$, directly from acoustic data (Fig. 2b, 2d \& 2f).

$r_{M}=9 \times 10^{-9}+3.3 \mathrm{E}-6.77 \mathrm{M}^{-2}$ 
$\mathrm{r}_{\mathrm{G}}=19.95 \mathrm{E}-9 \mathrm{G}^{-0.5}$

$r_{K}=6 \times 10^{-9}+3 \mathrm{E}-6.77 \mathrm{~K}^{-2}$

were moduli are given in $\mathrm{GPa}$ and $\mathrm{r}_{\mathrm{M}}$, is pore radius from compressional modulus, $\mathrm{r}_{\mathrm{G}}$, from shear modulus and $r_{K}$ from bulk modulus.

Permeabilities, k (Fig. 2), were modeled by using eqn. (6) to (8) and Kozeny's relation so that we will have eqn. (9) to (11) as follows:

$$
\begin{aligned}
& \mathrm{k}_{\mathrm{M}}=\mathrm{c}\left(\varphi \mathrm{r}_{\mathrm{M}}^{2} / 4\right) \\
& \mathrm{k}_{\mathrm{G}}=\mathrm{c}\left(\varphi r_{\mathrm{G}}^{2} / 4\right) \\
& \mathrm{k}_{\mathrm{K}}=\mathrm{c}\left(\varphi r^{2}{ }_{\mathrm{K}} / 4\right),
\end{aligned}
$$

Where, $\mathrm{c}$ is Koenig's constant and $\varphi$ is porosity.

\section{Results}

Experimental data from Cenozoic and Jurassic shale's of Scold Flank-1 well (Mbia et al., 2011) and that of gadolinite and steatite aggregates (Mongol et al, 2007) were used to calculate compression modulus which vary from 4 to 40 Gap, shear modulus (0.1 - 8 Gap) and bulk modulus (4 - 35 Gap) and pore radius from BET, porosity and grain density $(1 \mathrm{E}-09-1 \mathrm{E}-07 \mathrm{~m})$. The cross plots of elastic module versus pore radius (Fig. 2.) were used to derived the empirical equations which can be used to predict pore radius and permeability from field data. The cross plots (Fig. 2a, 2c \& 2e) show that gadolinite, steatite and Cenozoic (containing gadolinite, interlayer illite/Smectite) blend together with very low elastic moduli and corresponding large pore radius. This is because Cenozoic shale including kaolinite and smectite aggregates are not cemented and in the mechanical compaction zone. The Jurassic samples at greater depth show very high elastic moduli with corresponding small pore radius. The high elastic moduli and small pore radius may indicate that this material has undergone some degree of cementation under chemical compaction. The predicted pore radius from compressional and bulk moduli anyway fits very well in linear scale ( $5 \%$ difference in some few data points) with that calculated from measured BET specific surface, grain density and porosity (Fig. 2b \& 2f) but that predicted from shear modulus shows some degree of scattering at higher values.

The empirical equations were used to derive permeability log from field data (Fig. 1) and the predicted permeability matched each other very well and shows the same depth trend from Cenozoic to Jurassic shale for the three equations. The predicted permeability for Cenozoic shale varies from 0.5 to $10 \mu \mathrm{D}$ while that of Jurassic shale vary from 0.0001 to $0.5 \mu \mathrm{D}$. It implies that one can use compressional or shear velocity to predict pore radius and thus permeability. 


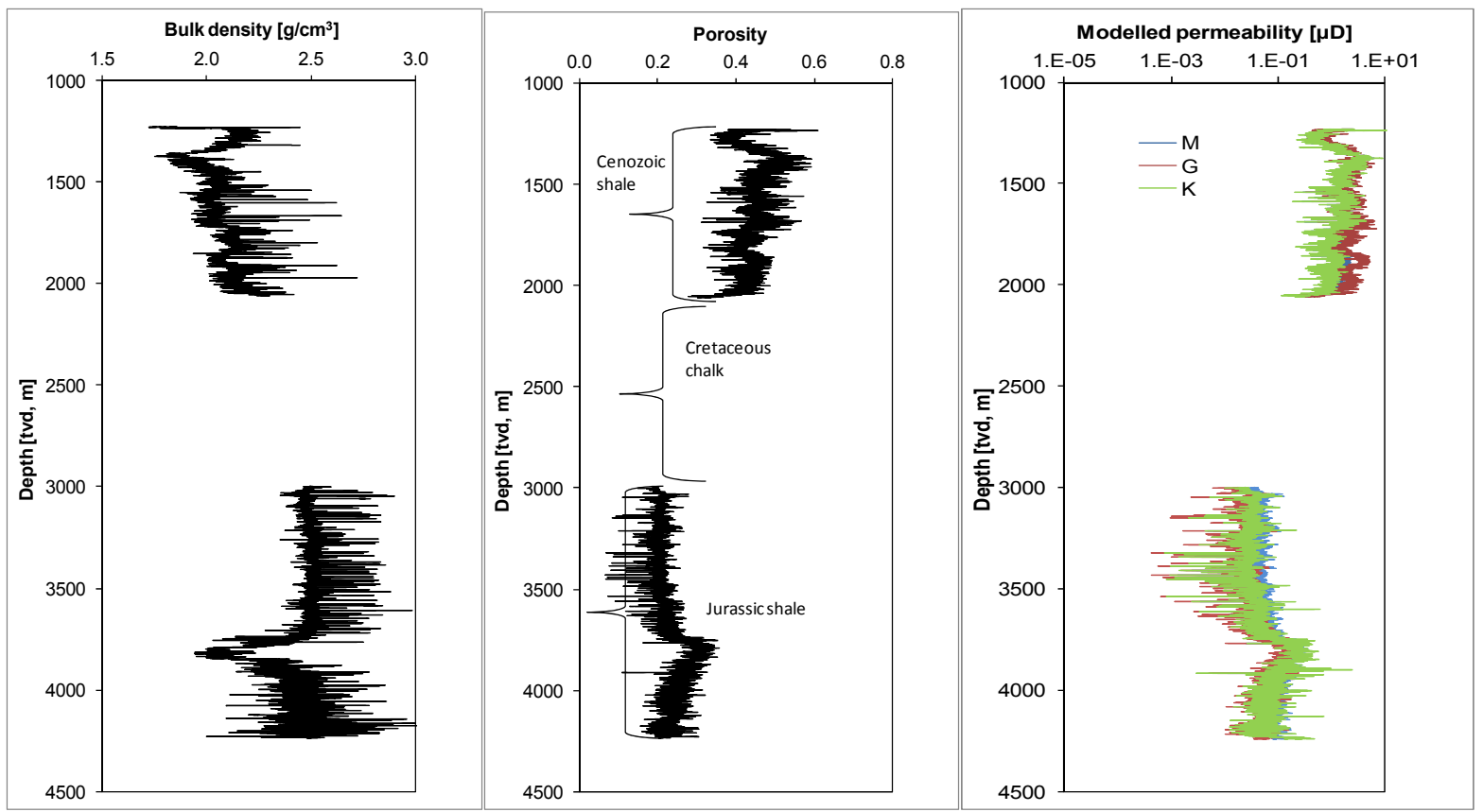

Fig.1. Depth plot of density, porosity and predicted permeability of shale intervals from of Skjold Flank-1 well. 

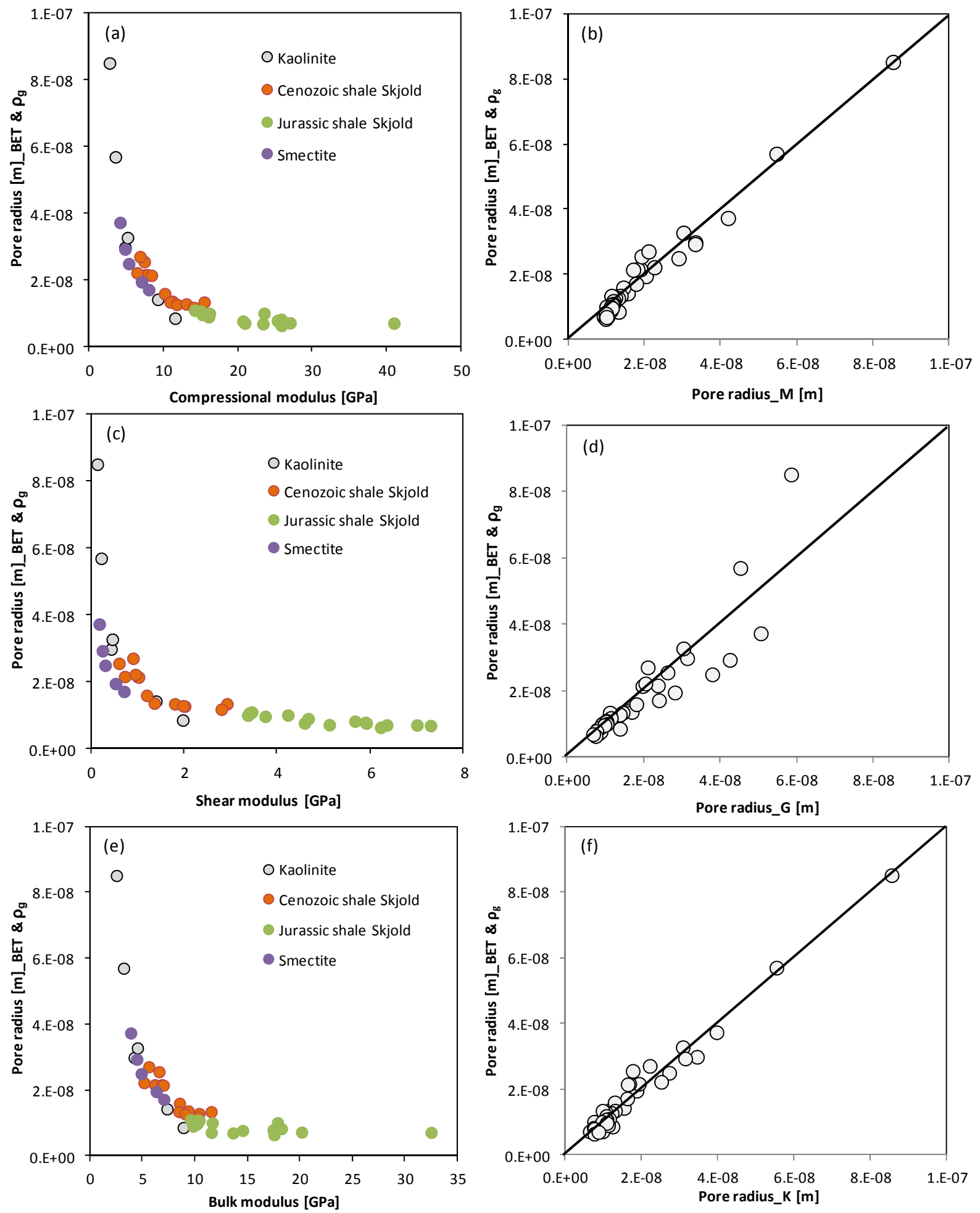

Fig.2. Cross plots of calculated pore radius versus predicted pore radius and moduli. (a) pore radius calculated from BET specific surface, porosity and grain density versus compressional modulus, (b) calculated pore radius versus the predicted pore radius from $M$, (c) calculated pore radius versus shear modulus $G$, (d) calculated pore radius versus pore radius predicted from shear modulus $G$, (e) calculated pore radius versus bulk modulus $K$, $(f)$ calculated pore radius versus pore radius predicted from bulk modulus, $K$. 


\section{Conclusions}

The empirical equations developed (eqn. 6 - 11) can be applied to field data to predict pore radius and permeability of shale in the depth interval of mechanical compaction and will give a fair estimate in shale that have underdone degree of cementation at greater depth.

This result is very important for field applications and can be very useful for $\mathrm{CO}_{2}$ storage and for other engineering applications. It should be noted that in order to validate these findings more experimental work is needed to be done on extensive shale samples from different locations.

\section{Acknowledgement}

We thank Vattenfall A/S for their financial support and Mærsk Oil and Gas AS for data and also Sinh Hy Nguyen for his technical assistant.

\section{References}

Fabricius, I. L. 2011: Relationship between Elastic Moduli and Pore Radius in Clay Aggregates. 73rd EAGE Conference \& Exhibition incorporating SPE EUROPEC 2011 Vienna, Austria, 23-26 May 2011.

Fabricius I. L., Baechle G., Eberli G.P., Weger R., 2007, Estimating permeability of carbonate rocksfrom porosity and Vp/Vs, Geophysics, 72, E185-E191.

Kozeny, J. 1927. Uber Kapillare Leitung des Wassers im Boden: Stizurgsberichte. Akademie der Wissenschaften in Wien, 136, 271-306.

Mari J.L., Gaudiani P., Delay J., 2011. Estimating Permeability from Acoustic Attenuation and Porosity - Field Example of a Carbonate Formation. 73rd EAGE Conference \& Exhibition incorporating SPE EUROPEC 2011 Vienna, Austria, 23-26 May 2011.

Mavko, G., Mukerji, T., and Dvorkin, J. 2009. The Rock Physics Handbook 2ed. Cambridge U.P. $511 \mathrm{pp}$.

Mbia, E. N., Fabricius, I. L., Oji. C. O. 2011. Petrophysics of Shale Intervals in the Skjold Field, Danish North Sea. 73rd EAGE Conference \& Exhibition incorporating SPE EUROPEC 2011 Vienna, Austria, 23-26 May 2011.

Mondol, N.H., Bjørlykke, K., Jahren, J., and Høeg, K. 2007. Experimental mechanical compaction of clay mineral aggregates -Changes in physical properties of mudstones during burial. Marine and Petroleum Geology 24, 289-311.

Mondol, N.H., Bjørlykke, K., Jahren, J., and Høeg, K. 2008. Experimental compaction of clays: relationship between permeability and petrophysical properties in mudstones. Petroleum Geoscience, 14, 319-337 